\title{
The impact of supply chain quality integration on green supply chain management and environmental performance in Vietnam's tourism industries
}

\author{
Manh Dung Trana, Thi Thu Hien Phan ${ }^{b^{*}}$, Hong Hanh Ha ${ }^{a}$ and Thi Thu Ha Hoang ${ }^{a}$
}

${ }^{a}$ National Economics University, Hanoi, Vietnam

${ }^{b}$ University of Economics - Technology for Industries, 456 Minh Khai, Hai Ba Trung, Ha Noi, Vietnam

\begin{tabular}{l}
\hline C H R O N I C L E \\
\hline Article history: \\
Received May 5, 2020 \\
Received in revised format June \\
8,2020 \\
Accepted August 122020 \\
Available online \\
August 122020 \\
\hline Keywords: \\
Supply chain quality integration \\
Green supply chain management \\
Environment performance \\
Tourism, Vietnam
\end{tabular}

\section{A B S T R A C T}

\begin{abstract}
The objective of this paper is to assess the impact of supply chain quality integration on green supply chain management, environment performance and financial performance. The data was analyzed on 568 Vietnamese tourism businesses. Results were analyzed using SPSS 22 and Smart PLS 3.6 software. The results show that supply chain quality integration had a positive impact on green supply chain management and financial performance. Green supply chain management also had a positive impact on environment performance and financial performance. Green supply chain management also played a full mediating role in the relationship between supply chain quality integration and financial performance. However, neither size nor institutional pressure played any moderating role in the relationship between green supply chain management and financial performance and environment performance.
\end{abstract}

\section{Introduction}

Increasing environmental awareness of the whole society, the government has developed various approaches to environmental protection, such as establishing stricter environmental regulations, promoting cleaner production, and promoting encourage certification of ISO 14001 (Zhu \& Sarkis, 2004). The manufacturing industry is required to emphasize environmental protection and green production has become one of the strategic missions. Many of the environmental problems are not caused by the manufacturer's internal operations but are related to its upstream and downstream supply chains. Environmental initiative and initiatives that require supply chain collaboration and awareness and the ability to protect the environment of supply chain partners are also important. To reduce environmental pollution and establish an environmental image, tourism businesses must actively collaborate with suppliers and their customers to implement green supply chain management (GSCM). Integrating supply chain management will improve the efficiency of green supply chain management and environmental efficiency in Vietnam's tourism businesses. The current situation of tourism development in Vietnam shows that there are already existing links between the participants in the tourism supply chain to form an integrated tourism product provided to tourists. Links under management organizations (State management agencies, private enterprises, joint ventures with foreign countries). This connection is expressed through activities of management, implementation, and supervision of the implementation of laws and agreements in tourism business activities. On the side of State management, a series of related mechanisms, policies and institutions that have a positive impact, creating a foundation to promote tourism development has been formed and renewed in accordance with the conditions and trends. developing world and domestic tourism. Legal documents related to tourism such as the Ordinance on entry, exit, residence and travel for Vietnamese people; for foreigners and other relevant documents are supplemented; Procedures for entry, exit,

* Corresponding author +840914915926

E-mail address: hien.aasc@gmail.com (T.T.H. Phan)

C 2020 by the authors; licensee Growing Science. doi: $10.5267 /$ j.uscm.2020.8.003 
residence, travel, customs are continuously improved, making it more convenient for guests and investors. The highlight of the tourism industry is that in early 2017, the Politburo issued Resolution No. 08 on developing tourism became a key economic sector. The XIV National Assembly passed the Tourism Law (amended). The government also adopted two visa policies for foreigners, which were to pilot e-visas for foreigners entering Vietnam and continue to extend visa-free visas for tourists from five Western European countries. (England, France, Germany, Italy and Spain), creating favorable conditions for tourists' travel, contributing to maintaining a high growth rate of international visitors to Vietnam. In the past, regional links between localities have been formed spontaneously in the form of creating specific tourism programs. Many promotion programs have been coordinated by the three localities to develop a strategy to promote such as "Da Nang called sea", "Quang Nam - Heritage journey"; "Lang Co legend of the sea"; "Three localities - a destination." The cooperation between the three localities has brought the Central Tourism brand to domestic and foreign tourists as the ideal destination of Vietnam, thereby contributing to attracting domestic and foreign tourists. creating more jobs and budgets for localities. Tourism businesses and tourism management agencies maintain vertical links from central to local levels to provide services to tourists, as well as direct the management of tourism development according to strategy and general orientation. Regarding State management, the General Department of Tourism under the Ministry of Culture, Sports and Tourism is the central agency with the function of advising and helping the Ministry carry out the tasks and powers of state management of tourism within the whole scope. Locally, this function belongs to the Department of Culture, Sports and Tourism or the Department of Tourism. Many large tourism businesses also form local representative offices to implement local affiliate activities in tourism business operation. Links by business lines (travel, hotels, passenger transport, including air transport) are mainly performed through the tourism businesses in each business sector to sign contracts to serve tourists in a tourism program.

In the tourism supply chain, travel businesses act as a bridge between supply and demand in tourism activities. In Vietnam in recent years, travel businesses are the leading units in attracting millions of international tourists to Vietnam and promoting the growth of domestic tourism, meeting the demand for travel. Travel agencies organize package tour programs to provide for tourists. Tours are often referred to as specific tourism products, which include basic services to meet the travel needs of everyone. Thus, when building tours, travel agencies had to closely associate with tourist accommodation establishments, travel transport firms (including aviation) and other service enterprises based on business contract. When a tour is conducted, it has the participation of many businesses with different industries. Previously in this linkage, tour operators often played a major role in distributing guests and distributing benefits to other businesses participating in the tourism supply chain. However, with the development of information technology, nowadays the trend of tourists arranging for their own trips without going through travel agencies or buying tour programs is increasing. With this trend, the role of travel businesses is increasingly limited in the tourism value chain. In the tourism supply chain, the role of hotel and accommodation businesses is increasing in tourism business links. Most hotels have set up a direct marketing system to tourists, reducing dependence on travel businesses through advertising channels, booking on the Internet. Hotels have proactively focused on diversifying products and services, improving service quality to meet the increasingly diverse needs of tourists, focusing on regular guests.

Integrated different components in the supply chains of businesses helps businesses manage their green supply chains, operate more efficiently, and reduce environmental impacts. In the world, there have been many studies on this topic, but very few studies have been carried out in the field of travel. Moreover, previous studies have not yet tested the mediating role of GSCM in the relationship between SCQI and financial performance and the moderating role of firm size in the relationship between GSCM and financial performance.

The structure of the article in addition to the introduction includes the following sections: Research overview, research methods, research results and conclusions. The objective of this paper is to assess the impact of SCQI on other aspects of the business such as green supply chain management, financial efficiency and environmental performance of Vietnamese tourism businesses.

\section{Literature review}

\subsection{Supply chain quality intergration}

The supply chain is the process by which an organization produces 1 product from raw materials supplied by different companies and then, sells to customers. Depending on the size of the organization and the number of products produced, the supply chain can become either complex or simple. Supply chain management is the management of a network of businesses involved in the supply of goods and services to consumers. It requires many different processes, including storage, material transport \& inventory handling \& manufacturing \& storage, transporting complete goods from production to consumption. Supply chain quality integration (SCQI) is the degree to which internal business units integrate with external supply chain partners including suppliers and customers to manage the value chain together, business activities such as communication, quality links to achieve the highest performance and cut operating costs (Huo et al., 2014). According to Yu et al. (2017) SCQI consists of three constituent aspects: integration within the enterprise, integration with suppliers and integration with customers. Integration within the enterprise includes activities related to integrating internal quality of the enterprise, activities of developing strategies, practices and business processes within the enterprise, synchronization among departments and departments to achieve the highest business efficiency, to meet the needs of 
customers (Huo et al., 2014). External integration links include Supplier quality integration and Customer quality integration. External quality integration is the extent to which businesses integrate with external partners to implement business strategies that meet the needs of customers and suppliers. External quality integration is the core competency of an enterprise to coordinate its supply chain, and it will have functional activities that coordinate the operations of its key suppliers and customers to achieve operational goals (Yu \& Huo, 2017).

\subsection{Green supply chain management}

From product design to production process development and logistics management, the supply chain has a major impact on the environment. A green supply chain can be defined as the process of using environmentally friendly inputs and transforming the by-products of use into something that can be improved or recycled in the current environment. This process enables the outputs and by-products to be reused at the end of their lifecycle, thus creating a sustainable supply chain.

Put simply, a green supply chain is an efficient supply chain that is environmentally friendly and effectively utilizes natural ecological resources. Green supply chain management is the integration of environmental factors into supply chain management, including product design, sourcing and selection of raw materials, production processes, and distribution of final products to consumers. use and end-of-product management after using it. Green supply chain management involves traditional supply chain management practices that integrate environmental standards or concerns into organized procurement decisions and long-term relationships with suppliers. Green supply chain management is associated with the governance of its links, including green design, green operations, green procurement, green input and output logistics, waste management, green production, etc.

Green supply chain management has many benefits: For the environment: green supply chains help reduce waste, reduce waste and reduce pressure on the environment. For the economy: the green supply chain helps improve production processes, reduce raw material costs, create competitive advantages, increase flexibility and link with partners. For society, it helps to protect human health, reduces the negative impacts from industrial waste and the negative impacts on the community and demonstrating social responsibility of each enterprise.

GSCM is the business activities, plans, business strategies that synchronize environmental protection goals in the supply chain management of enterprises to improve the environmental performance of businesses and suppliers. levels and customers (Bowen et al., 2001). GSCM is a comprehensive integration of environmental protection goals, including product design, material sourcing, production processes, product sales and after-sales service (Srivastava, 2007). The goal of GSCM is to limit negative impacts on the environment throughout the supply chain including from supplier to production and consumption (Curkovic \& Sroufe, 2011).

\subsection{Impact of Green supply chain management on Environment performance, Financial performance}

The impact of GSCM on environmental performance has been mentioned a lot in previous studies (Jacobs et al., 2010). Manufacturing and service businesses integrate environmental goals into green procurement, green production, and green consumption activities thereby positively impacting environmental performance (Choi et al., 2012; Chiou et al., 2011). The lives of consumers are getting higher and higher, consumers now buying products and using services are also interested in the environmental impacts of products and services, so that green consumption helps to improve the value of products. products and help manufacturers and service providers help businesses set up a better environment image than their competitors (Zhu \& Sarkis, 2004, Zhu et al., 2017). With the purchase of green, we help businesses combine with suppliers implement environmental projects to help reduce costs, reduce environmental effects and thereby improve environmental performance. Green consumption with customers helps businesses design, manufacture products, provide service packages to limit negative impacts on the environment thereby improving environmental performance (Vachon \& Klassen, 2008). Consumption of green, helps businesses produce and provide service packages comply with environmental regulations of all different markets, thereby improving the performance and competitiveness of businesses (Yang et al., 2018; Yang, 2018).

Thus, the positive relationship between GSCM and environmental performance has been mentioned quite a lot in previous studies, both in manufacturing and service provision. However, studies proving the mediating role of environmental performance in the relationship between GSCM and financial performance are still conflicting and there is no clear evidence, especially in the tourism industry (Zhang \& Yang, 2016). Application of GSCM activities helps reduce negative environmental impacts, significantly reduces waste and that reduces costs, which means increasing financial efficiency for businesses (Zhang and Yang, 2016; Lee et al., 2012).

\subsection{Moderate Size and Institutional pressures}

GSCM is a measure to help improve the reputation and environmental performance of businesses and help businesses create their competitive advantage. During the business operations, the environmental market, legal and environmental pressures of the business market itself also motivate enterprises to implement GSCM more effectively. Manufacturers and service providers must apply policies on the purchase and consumption of green products (Dubey et al., 2015). The market is fiercely competitive, so GSCM activities help businesses make green policies to enhance their competitive advantage and operational efficiency and environmental efficiency. According to institutional theory, the institutional pressures force units 
to implement GSCM and thereby improve environmental performance. For countries and localities that have severe institutional pressure on environmental protection, enterprises will be able to take GSCM activities more seriously, thereby improving environmental performance more. In contrast to localities, countries with looser environmental protection regulations will make businesses less serious in implementing environmental protection activities and GSCM activities from there. reduce environmental performance. For Vietnam, the closure of tourist areas and destinations heavily affected by environmental pollution has not yet been applied. Our paper hopes to find the moderating role of institutional pressure to help Vietnamese tourism businesses take better measures to protect the environment.

Another aspect that we are interested in is that, for large-scale businesses, GSCM activities will be more methodical and they will have funding to implement GSCM activities, which will bring benefits. Comprehensive benefits will make financial efficiency increasingly better. As for the smaller businesses, they do not have enough financial capacity to carry out GSCM activities. Therefore, the more GSCM is implemented, the worse the financial situation of the business is. From there we examine the moderating role of firm size in the relationship between GSCM and financial performance.

\subsection{Mediate Environment performance, Green supply chain management}

When businesses conduct integrated supply chain quality management, the coordination between business partners from suppliers to customers can be conducted smoothly and effectively for businesses. Based on the theory based on resources, we believe that the integration of supply chain quality will help businesses greening from input materials, choosing suppliers, buying green goods. Following the production process, businesses will carry out green production, green planning and thereby the process of consuming products and providing services is also green. When activities are greened synchronously from the input stage to the process of consuming products and services, it will help businesses save costs, improve their reputation, attract highly qualified employees, and create trust with customers as well as customer loyalty. Therefore, we believe that green supply chain management plays a mediating role in the relationship between SCQI and the financial performance of Vietnamese tourism businesses.

When businesses perform green supply chain management, they will conduct responsible purchasing, using green inputs for production and service provision. At the same time, when businesses perform green supply chain management, the production process is also green, the service provision process is also implemented under the goal of greening and protecting the environment. Since then, environmental performance is improved, reducing negative impacts on the environment, improving the image and reputation for businesses. The synchronization from the procurement, production and supply processes has been streamlined, protecting the environment, helping to improve employee productivity, cost savings and financial efficiency for businesses. Therefore, we believe that environmental performance plays a mediating role in the relationship between green supply chain management and the financial performance of Vietnam's tourism and travel businesses.

\section{Research method}

\subsection{Context and research sample}

Along with the country's renovation cause over the past 20 years, the tourism industry has made great progress and achieved remarkable achievements. Visitor, income, GDP and employment ratios have affirmed the role of tourism in the national economy. Undeniably, the tourism industry has made an important contribution to economic growth, hunger eradication and poverty reduction, ensuring social security, preserving and promoting cultural values, protecting the environment and maintaining security. security and defense. In the coming period, Vietnam tourism continues to maintain the view of sustainable development with the goal of developing tourism truly becoming a key economic sector and making Vietnam an attractive and high-class destination in Vietnam. area. To achieve that goal, the tourism industry needs to focus on developing quality, branded, professional and modern tourism based on optimizing the exploitation of national resources and advantages, promoting interdisciplinary, interregional, and socialized and motivational role of enterprises. For product development and market orientation, it is necessary to focus on building a system of typical and high-quality tourist products based on promoting the unique value of tourism resources, having outstanding strengths. Give priority to developing sea tourism; developing cultural tourism as a basis, developing eco-tourism, green tourism, and responsible tourism; linking regional product development in association with economic corridors.

Vietnam has 3,260 km long coastline, with 125 beaches, most of which are very beautiful beaches and convenient for tourism exploitation that not all countries have such as: Tra Co, Ha Long, Lang Co, Da Nang, Nha Trang, Phu Quoc, etc. Regarding cultural and historical relics, the country has 85 relics classified as special national monuments, 3,329 relics classified as national monuments and 9,857 provincial relics. Up to now, Vietnam has 8 tangible heritage sites and World Heritage sites, which are: Hue Monuments Complex, Ha Long Bay, My Son Sanctuary, Hoi An Ancient Town, Phong Nha - Ke Bang National Park, Thang Long Imperial City Center Area, Ho Dynasty Citadel and Trang An Scenic Area. Vietnam has a large treasure of intangible cultural heritage with 191 heritages belonging to 7 types of intangible cultural heritage of ethnic groups living in all parts of the country included in the List of Cultural Heritage National intangible objects.

The socio-economic situation report from the General Statistics Office shows that the total revenue from tourists in 2019 reached 726,000 billion VND (about 31 billion USD), an increase of more than 17\% compared to 2018. In 2019, Vietnam 
has welcomed more 18 million international visitors - an increase of $16.2 \%$ compared to 2018 . Data show that nearly $80 \%$ of international visitors to Vietnam from Asia, with more than 14.3 million visitors and an increase of $19 \%$ over the same period; visitors from Europe were approximately 2.17 million arrivals - an increase of $6.4 \%$ and visitors from America 973,800 arrivals - an increase of $7.7 \%$.

Besides the achievements, Vietnam's tourism industry also faces many difficulties. The problem of plastic waste pollution in the sea has become alarming and urgent. According to statistics, Vietnam produces plastic waste of $0.28-0.73$ million tons per year (equivalent to $6 \%$ of the world's total plastic waste discharged into the sea).

Our sample is 568 Vietnamese travel businesses. We conduct the survey for 3 consecutive months from September to December 2019. We have distributed all 1000 questionnaires by email and by post or in person. After three months, we collected 592 questionnaires after cleaning the remaining 568 valid surveys to be included in the data analysis.

\subsection{Research models}

The research model is as follows:

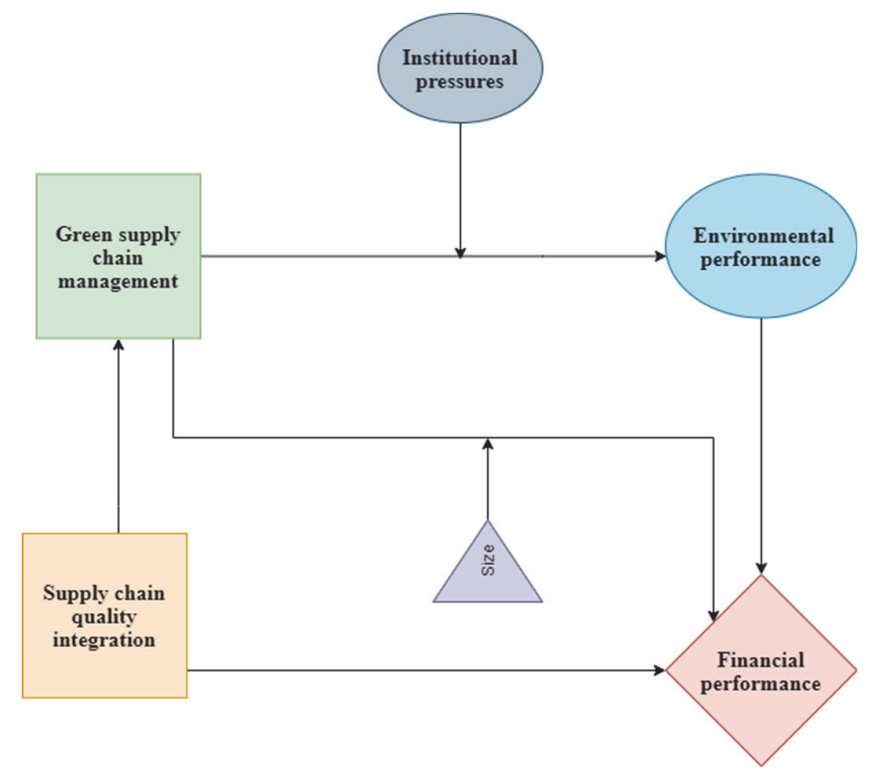

Fig. 1. Research model

The above research model with inherited research variables develops from the previous previous studies as follows:

SCQI: Is the integration of supply chain management in businesses, including 3 aspects of Internal, suppliers, customers. Internal quality integration is measured by 10 items, Supplier quanlity integration is measured by 9 items, and Customers quality integration is measured by 10 items. These items were developed from research by Yu et al. (2017); Huo et al. (2014; 2019); Flynn et al. (2010); Jacobs \& Mafini (2019); Fish, L.A. (2011); Flynn \& Flynn (2005). The scales are measured by a 5-point likert scale from 1 for totally agree to 5 which means totally disagree.

GSCM is an enterprise's green supply chain management activity, measured through 5 aspects of green production / green service provision, green purchasing, eco-design, green cooperation with customers and GIS. The scales for aspects of GSCM were developed from the study of Kalyar et al. (2019). 30 items are measured using a 5-point likert scale from 1 being very low to 5 being very high.

Institutional pressures: This includes regulations, sanctions, institutional pressures, enforcement on environmental management, waste treatment, and discharge for businesses. The scales of the institutional pressure transformer were developed from the study of Zhu et al. (two thousand and thirteen). 16 items measured using a 5-point likert scale is not important and 5 is very important.

Environmental performance is the efficiency, results in the protection of the environment and natural resources. The scales were developed from the study of Zhu et al. (2008). 8 items that measure environmental performance are measured by comparison with the industry average over the past 3 years. It is assessed by the judgment of the business management through a likert scale of 5 points from 1 which is much lower and 5 is much higher.

Financial efficiency: The indicators show the financial health of the business. These metrics are measured by business executives based on their judgment when comparing their business results against the industry average for the past 3 years. 
Five measures of financial performance were developed from the study of Phan et al. (2019) and Le et al. (2019). All of these scales are measured with a 5 point likert scale from 1 which is much lower and 5 a lot higher.

The research hypotheses are as follows:

$\mathrm{H}_{1}$ : Supply chain quality integration has a positive impact on financial performance.

$\mathrm{H}_{2}$ : Green supply chain management has a positive impact on financial performance.

$\mathrm{H}_{3}$ : Supply chain quality integration has a positive impact on Green supply chain management.

$\mathrm{H}_{4}$ : Green supply chain management has a positive impact on Environment performance.

$\mathrm{H}_{5}$ : Environment performance has a positive impact on financial performance.

$\mathrm{H}_{6}$ : Green supply chain management plays a mediating role in the relationship between Supply chain quality integration and financial performance.

$\mathrm{H}_{7}$ : Environment performance plays a mediating role in the relationship between green supply chain management and financial performance.

$\mathrm{H}_{8}$ : Institution pressure has a moderating role in the relationship between green supply chain management and environment performance.

$\mathrm{H}_{9}$ : Size has a moderating role in the relationship between green supply chain management and financial performance.

\subsection{Analytical techniques}

The purpose of the study is to test the research hypotheses that test the mediating and moderating roles of the study variables.

Data collection techniques were implemented during the distribution of survey forms. After collecting the questionnaire, we proceed to remove the invalid questionnaire and enter data into the excel file. With the data in excel file, we proceed to enter data into SPSS 22 software to conduct the verification of the value and reliability of the scale. Next, we conducted EFA discovery factor analysis of the study variables. With the scales that ensure the conditions of reliability and validity, we conduct research hypotheses, evaluate once again the general reliability and evaluate the measurement model by software. Smart PLS 3.6.

We first tested the reliability of the scale by Cronbach's Alpha coefficient and the correlation of the total variable. The Cronbach's Alpha coefficient has a variable value in the segment $[0,1]$. In theory, the higher the coefficient, the better (the more reliable the scale). However, this is not entirely accurate because Cronbach's Alpha coefficients are too large (about 0.95 and above) to show that many observed variables in the scale do not differ, they are almost completely the same. Significantly, this phenomenon is called duplication in the scale (Hair et al. 2011, 2014, 2017; Hesenler et al. 2009; 2015). Corrected Item - Total Correlation $\geq 0.3$, the variable is satisfactory (Hair et al., 2011, 2014, 2017; Hesenler et al., 2009; 2015). Corrected Item - Total Correlation coefficient indicates the correlation between that observed variable and the remaining variables in the scale, if the observed variable has a stronger correlation with the variables in the group, the better that variable. Thus, when performing Cronbach's Alpha reliability test, the observed variable has a total correlation coefficient less than 0.3 , need that variable and run again next time.

If there are two observed variables with the Corrected Item - Total Correlation coefficient $<0.3$, we will remove them in the order of the observed variables with the smallest Corrected Item - Total Correlation. Cronbach's Alpha coefficient value level:

From 0.8 to close to 1 : very good measurement.

From 0.7 to nearly 0.8 : good measurement scale.

From 0.6 and above: eligible measurement scale (Hesenler et al. 2009, 2015).

Next, we conducted an EFA discovery factor test on SPSS 22 assessed using KMO and Sig coefficients.

Finally, we evaluate aggregate reliability, discriminant validity, evaluate measurement models, structural models and test research hypotheses using Smart PLS 3.6 using PLS and Boostrap techniques.

\section{Research results}

With the results of the reliability test of scales performed in SPSS 22, the scales have Cronbach's Alpha value greater than 0.6 ; the total correlation coefficient is greater than 0.4 , so all scales meet the conditions of testing reliability and validity of the scale. Next, we tested the discovery factor analysis, the results showed that the KMO coefficient was both greater than 
Table 4

The results of F-value

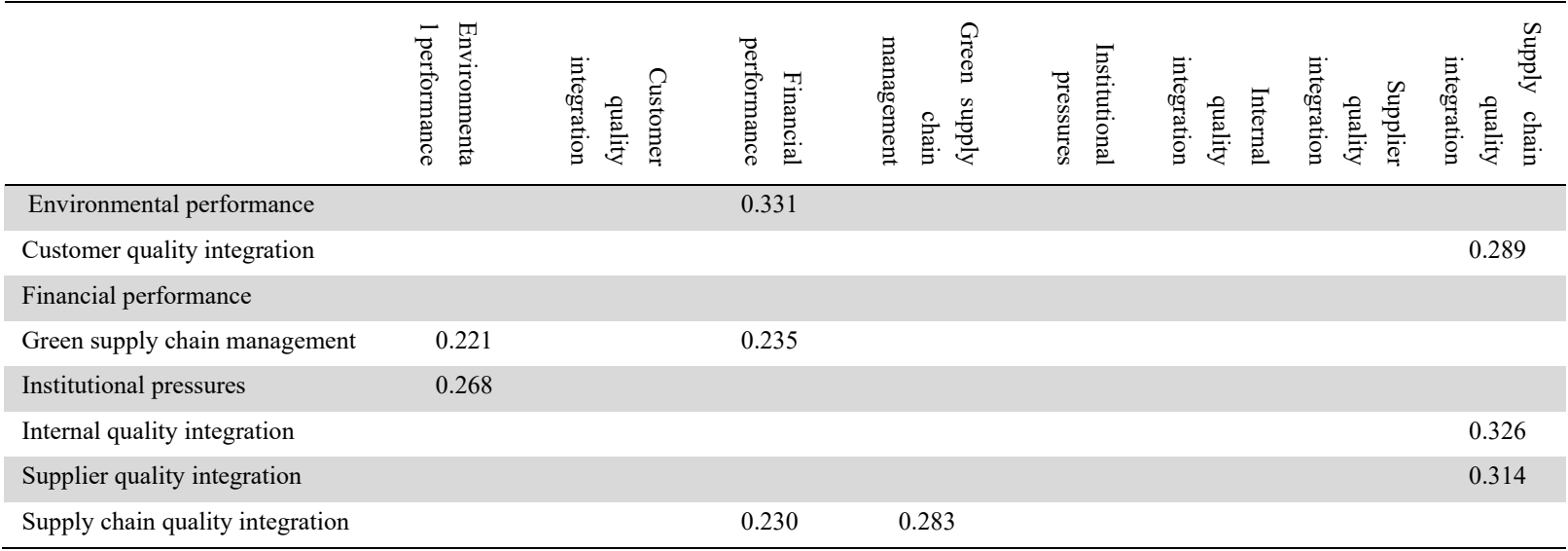

The values of f-square are all greater than 0.3, according to Henseler et al. (2015) all variables have a logical relationship with each other in the research model, satisfying the testing conditions.

Table 5

Model Fit Summary

\begin{tabular}{lll}
\hline & Saturated Model & Estimated Model \\
\hline SRMR & 0.053 & 0.055 \\
d_ULS & 0.962 & 0.991 \\
d_G & 0.512 & 0.539 \\
Chi-Square & $1,626.123$ & $1,682.521$ \\
NFI & 0.880 & 0.885 \\
\hline
\end{tabular}

Model fit results show that the SRMR value is less than 0.06 , the NFI is greater than 0.88 so that the research model is suitable for the research data (Hair et al., 2017, 2011, 2013; Henseler et al., 2009, 2015). When the initial conditions are met, we conduct research hypotheses. First with the PLS results as follows:

The impact coefficient results on Smart PLS 3.6 are given in Fig. 2 as follows:

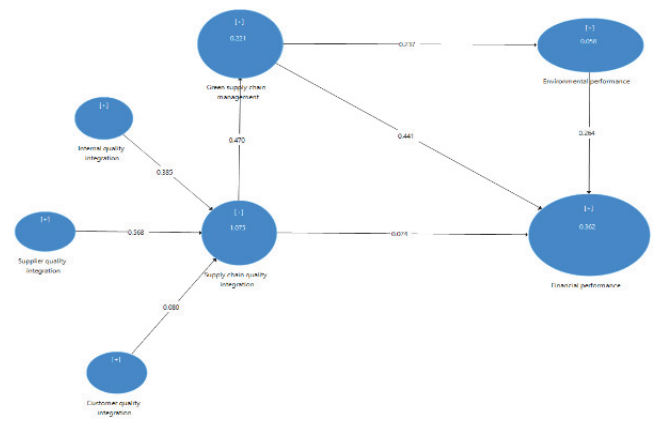

Fig. 2. Impact coefficient

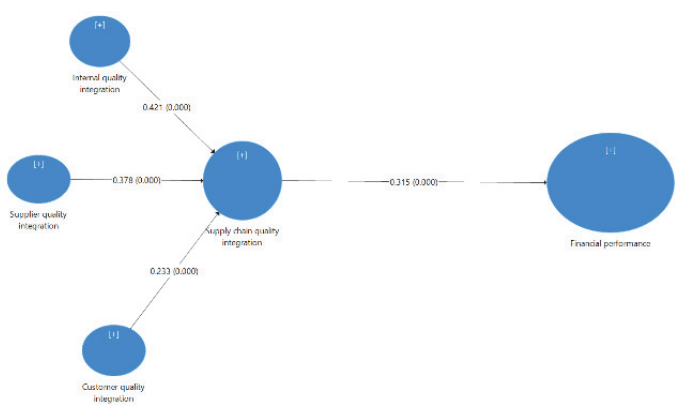

Fig. 3. Impact of Supply chain quality integration on Financial performance

The test results of the hypotheses are as follows:

We first tested the hypothesis H1: Supply chain quality integration has a positive effect on financial performance. The boostrap results are as follows:

From the results in Fig. 2, it shows that supply chain quality integration has a very strong positive impact on financial efficiency at 0.315 impact level with $1 \%$ significance level $(\mathrm{P}$ _value $=0.000)$. For Vietnamese tourism businesses, integrating the quality of internal and external supply chains helps these businesses improve their financial performance. This result is like the research of Yu \& Huo (2017). Integrating the implementation of supply chain quality from carefully selected suppliers ensures quality conditions, reduces wasted costs, and provides the most comprehensive service design. 
customer's need. Therefore, Supply chain quality integration has a positive impact on financial performance. It also means that it is qualified to conduct a mediating role test of green supply chain management in the relationship between supply chain quality integration and financial performance in the next step.

Next, we examine the direct impact of GSCM and financial performance. The testing results are given in Fig. 4 as follows:

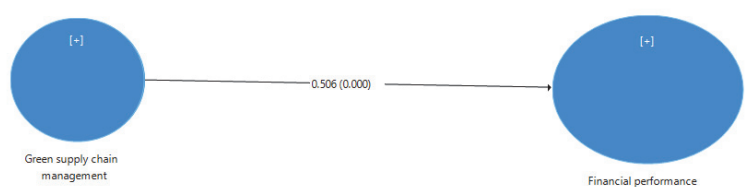

Fig. 4. Direct relationship between Green supply chain management and financial performance

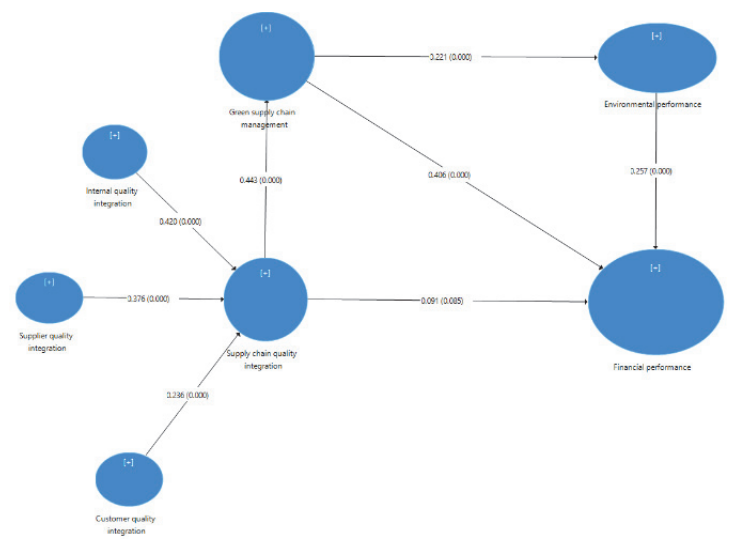

Fig. 5. Bootstrap results of the overall SEM model

The results of Fig. 4 show that Green supply chain management has a positive direct impact on the level of very strong impact on financial performance at the impact level of 0.506 at the $1 \%$ significance level $\left(\mathrm{P}_{-}\right.$value $\left.=0.000\right)$. This means that it is qualified to test the mediating role of Environment performance in the relationship between Green supply chain management and financial performance.

From the results in Fig. 2, Supply chain quality integration has a very strong positive impact on Green supply chain management with an impact factor of 0.443 at $1 \%$ significance level $\left(P \_\right.$value $\left.=0.000\right)$. This means that tourism businesses in Vietnam implementing a strategy to integrate supply chain quality both inside and outside the business will have a positive impact on the management of green supply chains. Implementing integrated supply chain quality, integrating supply chain with customers, integrating supply chain quality with suppliers will help green supply chain management activities be carried out more appropriatly. Vietnam travel businesses are service businesses, so it is important to integrate supply chain quality management from the selection of input products from eco-friendly suppliers. This will create environmentally friendly service packages and create an integrated green consumption process with customers. This will help improve the efficiency of green supply chain management. Today, tourism businesses often combine indigenous mining tourism, integrated nature conservation right from the time of destination selection, products and services to provide customers to the process of leading. Tour guides also guide tourists to protect the environment. All integrated activities are synchronized from the provider to the service delivery process to the customer service operation. Green supply chain management has a strong impact on Environment performance with an impact coefficient of 0.221 at $1 \%$ significance level $(\mathrm{P}$ value $=0.000)$. Vietnam travel businesses, implementing green supply chain management, will have a positive impact on environmental performance, which means that Vietnamese tourism businesses have controlled waste, negative impacts on the environment, reducing $\mathrm{CO} 2$ emissions and reducing plastic waste. Indeed, when green supply chain management is carried out, right from the selection of input products to form the tourism service package, at destinations, tourism businesses in Vietnam have known. Understand the importance of protecting the environment and reducing negative impacts on local ecosystems. Therefore, green supply chain management activities have a positive impact on environmental performance. However, in Vietnam, in our sample, most are small and medium-sized travel businesses, so the supply chain management activities have not been implemented much. The positive effect of green supply chain management to environmental performance is only moderate. Environment performance has a strong impact on Financial performance with an impact coefficient of 0.257 at the $1 \%$ significance level $\left(\mathrm{P}_{-}\right.$value $\left.=0.000\right)$. This means that environmental performance has a positive impact on financial performance. It is easy to understand that when environmental activities are controlled, enterprises will reduce emissions, emissions and administrative handling costs because of the violation of waste emission, which will help businesses reduce expenses and operational costs and improve financial efficiency. In addition, high environmental performance means that businesses choose products and provide good services, thereby creating a good image and brand in the market to help businesses attract more customers, which means higher revenue and higher financial efficiency. However, Supply chain quality integration does not have a statistically significant impact on financial performance or performance

Summary of bootstrap test results as follows: 
Table 6

The results of Path Coefficients

\begin{tabular}{|c|c|c|c|c|c|}
\hline & $\begin{array}{l}\text { Original } \\
\text { Sample (O) }\end{array}$ & $\begin{array}{l}\text { Sample } \\
\text { Mean (M) }\end{array}$ & $\begin{array}{l}\text { Standard } \\
\text { Deviation } \\
\text { (STDEV) }\end{array}$ & $\begin{array}{l}\text { T Statistics } \\
(|\mathrm{O} / \mathrm{STDEV}|)\end{array}$ & P Values \\
\hline Environmental performance $\rightarrow$ Financial performance & 0.257 & 0.256 & 0.046 & 5.543 & 0.000 \\
\hline Customer quality integration $\rightarrow$ Supply chain quality integration & 0.236 & 0.236 & 0.007 & 33.913 & 0.000 \\
\hline Green supply chain management $\rightarrow$ Environmental performance & 0.221 & 0.222 & 0.057 & 3.888 & 0.000 \\
\hline Green supply chain management $\rightarrow$ Financial performance & 0.406 & 0.408 & 0.046 & 8.844 & 0.000 \\
\hline Internal quality integration $\rightarrow$ Supply chain quality integration & 0.420 & 0.421 & 0.007 & 59.309 & 0.000 \\
\hline Supplier quality integration $\rightarrow$ Supply chain quality integration & 0.376 & 0.376 & 0.009 & 41.861 & 0.000 \\
\hline Supply chain quality integration $\rightarrow$ Financial performance & 0.091 & 0.092 & 0.053 & 1.722 & 0.085 \\
\hline Supply chain quality integration $\rightarrow$ Green supply chain management & 0.443 & 0.441 & 0.043 & 10.286 & 0.000 \\
\hline
\end{tabular}

Next, we examine the mediating role of Environment performance in the relationship between GSCM and financial performance. We verify the relationship between Green supply chain management and financial performance in the overall SEM model. In the overall SEM model in Fig. 5, Green supply chain management still has a statistically positive impact on financial performance at the impact level of 0.406 at the $1 \%$ significance level $(\mathrm{P}$ _value $=0.000)$ which means Environment Performance has no mediating role in the relationship between green supply chain management and firnancial performance. To test the mediating role of green supply chain management in the relationship between supply chain quality integration with financial performance, we look at the impact of supply chain quality integration on financial performance in the overall SEM model in Fig. 5. The results show that in the overall SEM model, supply chain quality integration no longer has a statistically significant relationship to financial performance, so green supply chain management has a full mediating role in this relationship. This means, hypothesis H6 is supported.

Finally, we examine the moderating role of size and institutional pressure. The following results:

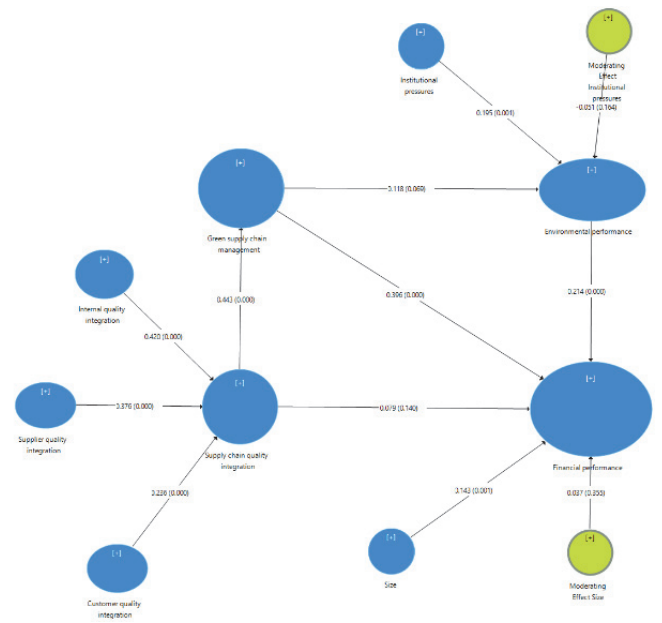

Fig. 6. Test results moderating role of Size and institutional pressure

The results in Fig. 6 show that Size has a statistically significant impact on financial performance at the impact level of 0.143 at the $1 \%$ significance level $(\mathrm{P}$ value $=0.001)$ eligible to test the regulatory role. However, the results of the moderator role show that the size of the moderator variable is not statistically significant. This means that there is not enough data to test the Size regulatory role. The same goes for institutional pressure in the relationship between green supply chain management and environment performance. Institutial pressures have a statistically significant impact on the environment performance at the 0.195 impact level with $1 \%$ significance level $\left(\mathrm{P}_{-}\right.$value $\left.=0.001\right)$. However, the regulatory variables of institutial pressures do not have a statistically significant effect on environment performance. Thus, hypothesis $\mathrm{H}_{8}$ and hypothesis $\mathrm{H}_{9}$ are not eligible to accept or we remove 2 hypotheses $\mathrm{H}_{8}$ and $\mathrm{H}_{9}$.

\section{Conclusion}

With the above test results, supply chain quality integration and green supply chain management activities have positive impacts on environmental performance and financial efficiency. This is like previous studies conducted in other countries such as Yu et al. (2017); Zhu et al. (2013) Lin et al. (two thousand and thirteen). From the research results, we recommend some of the following recommendations: 
Complete policies and legal documents to support cooperation and links between tourism businesses. At present, there is no official document or circular issued directly by the State for cooperation and links between tourism businesses. Most of the time, businesses themselves build links based on a number of legal documents with content related to tourism. Therefore, not only businesses do they face difficulties but even the State also faces many inadequacies in management issues. Increase investment in tourism infrastructure. Continue the program of supporting investment in tourism infrastructure in the period of 2011 - 2015 in the direction of prioritizing focus in some localities with national tourist areas and key tourist areas in the Central region - Central Highlands, tourist destination capable of attracting many tourists in the vicinity of tourist centers; forming uninterrupted tour routes between key tourist areas and between localities. Concentrating focus on transitional works to promote the efficiency of investment projects and researching and issuing mechanisms to mobilize resources for tourism infrastructure development. Actively creating images and brands for the Tourism industry. Continue to promote promotion activities, promote image creation and branding for Vietnam's tourism industry through tourism business activities such as promotion events, cultural activities, national tourism fairs. In the key markets, traditional markets as well as potential markets such as Germany, Russia, Japan, Korea, the United Kingdom, China and markets in the Southeast South Asia ... set up representative offices of Vietnam tourism in some key markets (the United States, Western Europe, Japan, South Korea ...) to effectively implement the introduction of Vietnam's destination image. Plan to promote tourism promotion of Vietnam in the planning year should be sent to localities from October of the implementation year so that localities have bases to plan tourism promotion and have conditions to coordinate participation. In addition, it is necessary to research key markets and new markets to develop long-term tourism promotion plans; At the same time, consider, decentralize and transfer funding to localities as a focal point for tourism promotion activities of the industry for each foreign market in which the locality has advantages.

In addition, protecting the tourism environment is extremely urgent. The State has strengthened direction of sectors and localities to strengthen coordination in adjusting the tourism environment, thoroughly solving the situation of manipulating, pinching, taking advantage of and deceiving tourists at tourist centers. schedule and environmental sanitation in tourist areas, destinations, and stops in which the main task is to build a system of public toilets up to standards for tourists.

Solutions for businesses

The business community also needs to concretize into business objectives and plans; identify their duties and responsibilities, strengthen links to improve tourism in Vietnam. Complete the business strategy and plan of the business in accordance with the actual conditions. In order for businesses involved in tourism business to be proactive and active in the process of cooperation and integration, each business needs to have specific, appropriate business strategies and plans. It is important that each business strategy and business plan should aim at a goal of developing the overall tourism industry strategy. Enterprises should attach importance to developing annual business plans; branding, empowering businesses; strengthen links to create strength in competition; active international integration; enhance access and update information, especially information on development policies and regulations on tourism. Exploit and use appropriate information. It is required that tour operators, accommodation businesses and transportation businesses need to establish an interconnected information system other than the internal information system of the business. Thus, issues related to joint tourism business activities will be quickly updated, captured and exchanged by each other through this information network.

\section{Acknowledgement}

This research was funded by National Economics University, Hanoi, Vietnam

\section{References}

Bowen, F.E., Cousins, P.D., Lamming, R.C., \& Faruk, A.C. (2001). The role of supply management capabilities in green supply. Production and Operations Management, 10(2), 174-189, doi: 10.1111/j.1937-5956.200.tb00077.x.

Chiou, T., Chan, H. K., Lettice, F., \& Chung, S. H. (2011). The influence of greening the suppliers and green innovation on environmental performance and competitive advantage in Taiwan. Transportation Research Part E: Logistics and Transportation Review, 47(6), $822-836$.

Choi, B., Kim, J., Leem, B., Lee, C. and Hong, H. (2012). Empirical analysis of the relationship between six sigma management activities and corporate competitiveness: focusing on Samsung group in Korea. International Journal of Operations \& Production Management, 32(5), pp. 528-550

Curkovic, S. \& Sroufe, R. (2011). Using ISO 14001 to promote a sustainable supply chain strategy. Business Strategy and the Environment, 20(2), 71-93

Dubey, R., Gunasekaran, A. and Ali, S.S. (2015). Exploring the relationship between leadership, operational practices, institutional pressures and environmental performance: a framework for green supply chain. International Journal of Production Economics, 160, 120-132.

Flynn, B. B., \& Flynn, E. J. (2005). Synergies between supply chain management and quality management: Emerging implications. International Journal of Production Research, 43, 3421- 3436.

Fish, L.A. (2011). Supply chain quality management, in D. Onkal (ed.), Supply chain quality management, supply chain management - Pathways for research, p. 26, In Tech Open, London. 
Hair, J.F., Ringle, C.M., \& Sarstedt, M. (2011). PLS-SEM: in deed a silver bullet, Journal of Marketing Theory and Practice, 19(2), 139-151.

Hair, J.F., Hult, G.T.M., Ringle, C., \& Sarstedt, M. (2013). A Primer on Partial Least Squares Structural Equation Modeling (PLS-SEM), Sage Publications Ltd, London.

Hair, J.F., Henseler, J., Dijkstra, T., Sarstedt, M., Ringle, C., Diamantopoulos, A., Straub, D., Ketchen, D., GTM, H., \& Calantone, R. (2014). Common beliefs and reality about partial least squares: comments on Rönkkö and Evermann, Organizational Research Methods, 17(2), 182-209.

Hair, J. F., Hult, G. T. M., Ringle, C. M., and Sarstedt, M. (2017). A Primer on Partial Least Squares Structural Equation Modeling (PLS-SEM), 2nd Ed., Sage: Thousand Oaks.

Henseler, J., Ringle, C.M., \& Sarstedt, M. (2015). A new criterion for assessing discriminant validity in variance-based structural equation modeling. Journal of the Academy of Marketing Science, 43(1), 115-135.

Henseler, J., Ringle, C.M. and Sinkovics, R.R. (2009). The use of partial least squares path modeling in international marketing, in Sinkovics, R.R. and Ghauri, P.N. (Eds), New Challenges to International Marketing, Emerald Group Publishing Limited.

Huo, B., Ye, Y., Zhao, X. \& Zhu, K. (2019). Supply chain quality integration: A taxonomy perspective. International Journal of Production Economics, 207(1), 236-246. https://doi.org/10.1016/j.ijpe.2016.05.004

Jacobs, E. \& Mafini, C., (2019). Transactional leadership, supply chain quality and business performance in the fast-moving consumer goods industry. Journal of Transport and Supply Chain Management, 13(0), a442. https://doi.org/10.4102/ jtscmv13i0.442

Jacobs, B.W., Singhal, V.R. \& Subramanian, R. (2010). An empirical investigation of environmental performance and the market value of the firm. Journal of Operations Management, 28(5), 430-441.

Lee, S.M., Tae Kim, S. and Choi, D. (2012). Green supply chain management and organizational performance. Industrial Management and Data Systems, 112(8), 1148-1180.

Le, T. T., Nguyen, T. A., Phan, T. T. H., Tran, M. D., Phung, X. T., Tran, T. T., \& Giao, K. N. (2019). Impact of corporate social responsibility on supply chain management and financial performance in Vietnamese garment and textile firms. Uncertain Supply Chain Management, 7(3), 679-690.

Lin, C., Kuei, C. \& Chai, K., (2013). Identifying critical enablers and pathways to high performance supply chain quality management. International Journal of Operations \& Production Management, 33(3), 347-370.

Phan, T. T. H, Doan, X. T., Nguyen, T. T. T. (2019). The impact of supply chain practices on performance through supply chain integration in textile and garment industry of Vietnam. Uncertain Supply Chain Management, 8(1), $175-186$.

Srivastava, S.K. (2007). Green supply-chain management: a state-of the-art literature review. International Journal of Management Reviews, 9(1), 53-80, doi: 10.1111/j.1468-2370.2007.00202.x.

Vachon, S., \& Klassen, R.D. (2008). Environmental management and manufacturing performance: the role of collaboration in the supply chain. International Journal of Production Economics, 111(2), 299-315.

Yang, C.-S. (2018). An analysis of institutional pressures, green supply chain management, and green performance in the container shipping context. Transportation Research Part D: Transport and Environment, 61, 246-260.

Yang, Z., Sun, J., Zhang, Y. and Wang, Y. (2018). Peas and carrots just because they are green? Operational fit between green supply chain management and green information system, Information Systems Frontiers, 20(3), 627-645.

Zhang, H., \& Yang, F. (2016). On the drivers and performance outcomes of green practices adoption: an empirical study in China. Industrial Management and Data Systems, 116(9), 2011-2034

Zhu, Q., \& Sarkis, J. (2004). Relationships between operational practices and performance among early adopters of green supply chain management practices in Chinese manufacturing enterprises, Journal of Operations Management, 22(3), pp. 265-289.

Zhu, Q., Feng, Y., \& Choi, S.B. (2017). The role of customer relational governance in environmental and economic performance improvement through green supply chain management. Journal of Cleaner Production, 155(1), 46-53.

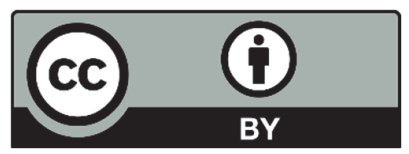

(C) 2020 by the authors; licensee Growing Science, Canada. This is an open access article distributed under the terms and conditions of the Creative Commons Attribution (CC-BY) license (http://creativecommons.org/licenses/by/4.0/). 